\title{
ELSEVIER_TECTO_126344
}

\section{Scaling, kinematics and evolution of a polymodal fault system: Hail Creek Mine, NE Australia}

Jacob Carvell ${ }^{a}$

Thomas Blenkinsop $\mathrm{a}^{\mathrm{a}, \mathrm{w}, *}$

BlenkinsopT@Cardiff.ac.uk

Gavin Clarke

Maurizio Tonellic

${ }^{a}$ Economic Geology Research Unit, School of Earth and Environmental Science, James Cook University, Queenstand QLD 4811, Australia

bSchool of Earth and Ocean Science, Cardiff University, Main Building, Park Place ${ }_{\perp}$ Cardiff CF10 3AT, United Kingdom

'Hail Creek Coal Mine, PO Box 3097, North Mackay, QLD 4740, Australia

${ }^{*}$ Corresponding author at: School of Earth and Ocean Science, Cardiff University, Main Building, Park Place Cardiff CF10 3AT, United Kingdom. Tel.: + 442920870232.

\section{Abstract}



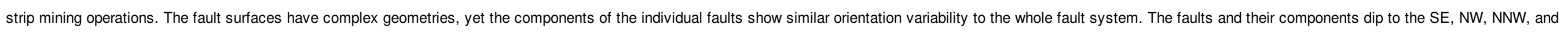

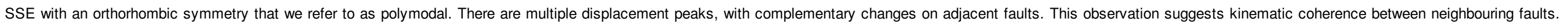

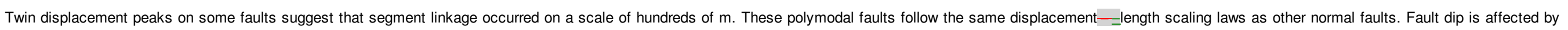

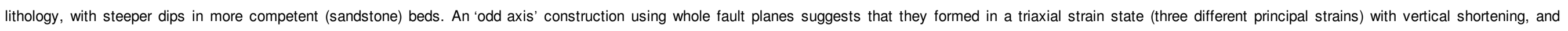

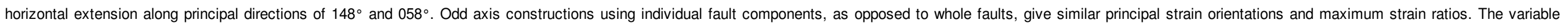

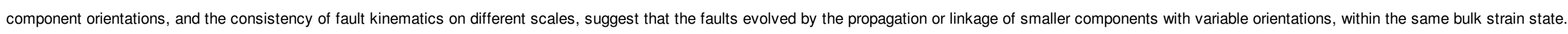

Keywords: Normal fault; Orthorhombic fault; Polymodal fault; Displacement_-length scaling; Coal; Mine

\section{Introduction}

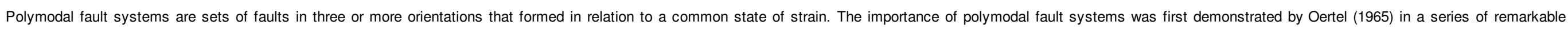

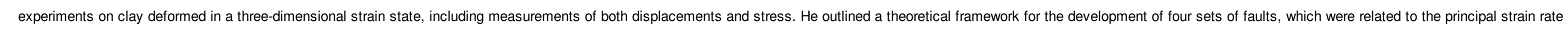

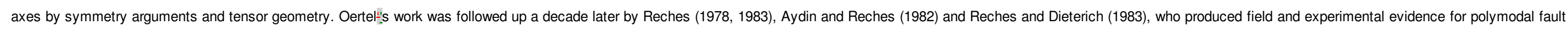

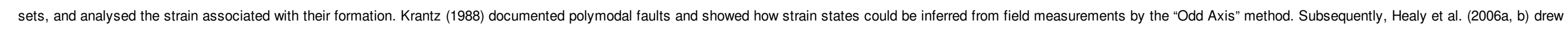

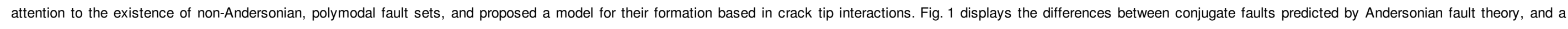
polymodal fault geometry. 


\section{ELSEVIER_TECTO_126344}

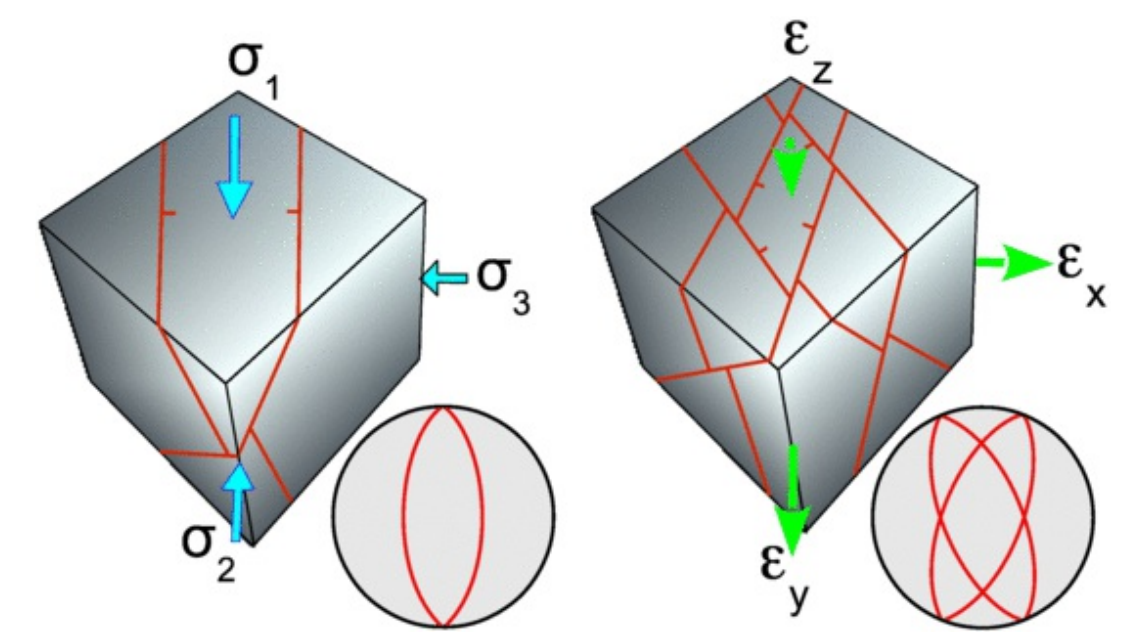

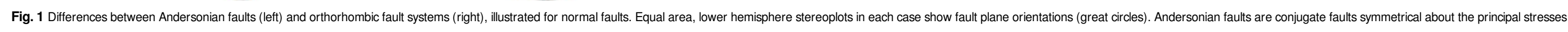
( $\sigma_{1} \geq \sigma_{2} \geq \sigma_{3}$, compression positive) (Anderson, 1951). Orthorhombic faults systems have four orientations symmetrical about the principal strains $\left(\varepsilon_{\mathrm{x}} \geq \varepsilon_{\mathrm{y}} \geq \varepsilon_{\mathrm{z}}\right.$, elongation positive) (cf. Reches, 1978).

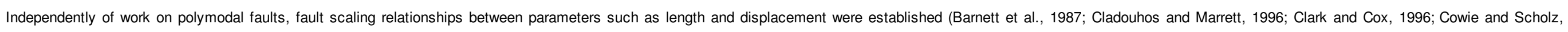



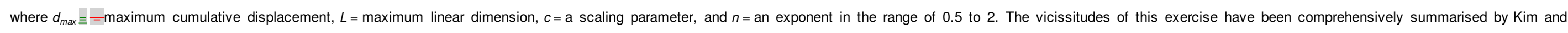
Sanderson (2005), who have concluded that displacement-length scaling depends on material property, type of fault, earthquake rupture and slip/propagation history, fault network evolution and reactivation.

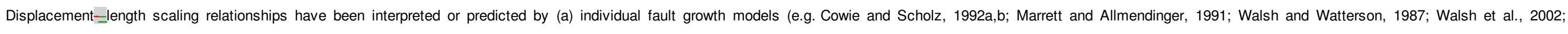

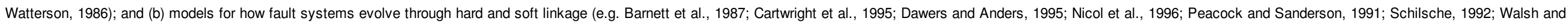

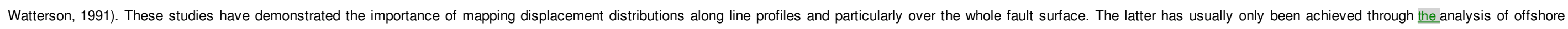
seismic reflection data (e.g. Alves, 2012; Nicol et al., 2005).

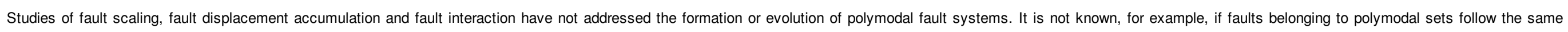
scaling laws as other faults, whether displacement exchange may occur between faults in a polymodal system, or how such systems evolve. The goal of the present study is to address these problems.


The strip mining and the large drilling and mining database at Hail Creek provide detailed information about the geometry and displacements of the faults, giving insights into the evolution of the fault system.

\section{Geological background}

\subsection{Stratigraphic context}

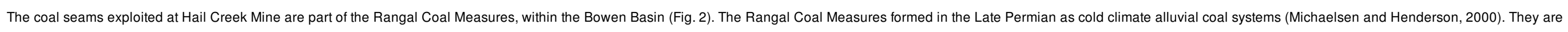

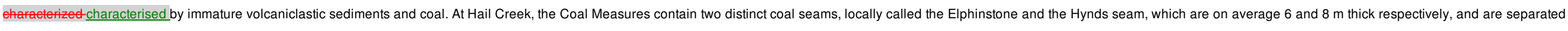

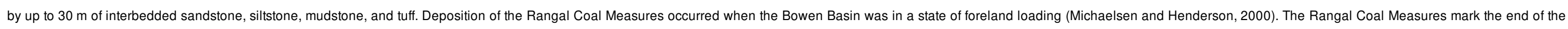
Permian, and are overlain by the Triassic Rewan Group. The contact between these two units is considered to be the Permian_-Triassic boundary. 


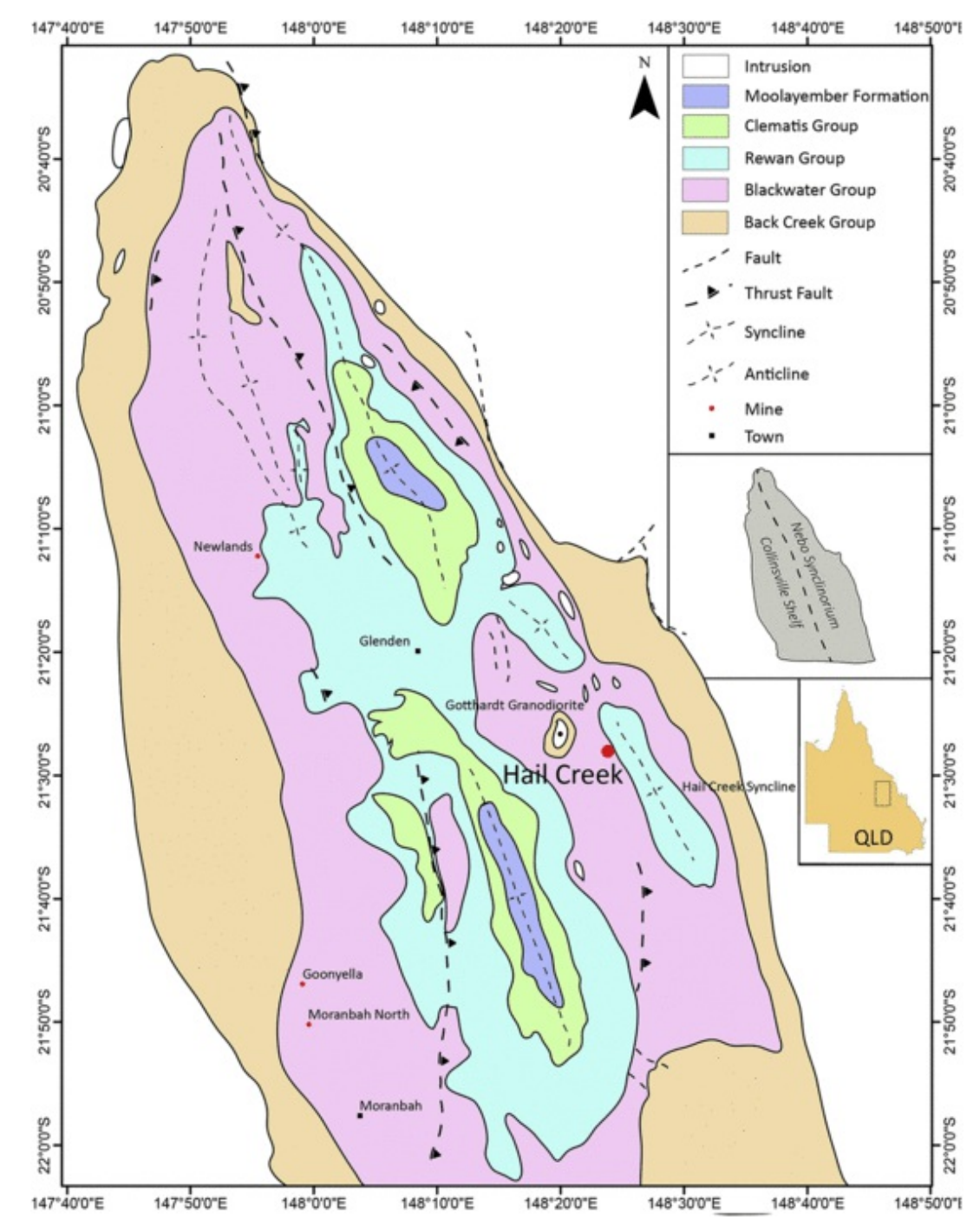

Fig. 2 Geological setting of Hail Creek Coal Mine in the Nebo Synclinorium, Bowen Basin, showing the doubly plunging folds and thrust fautts. Adapted from Mallet et al. (1995).

\subsection{Structural features of the Northern Bowen Basin}

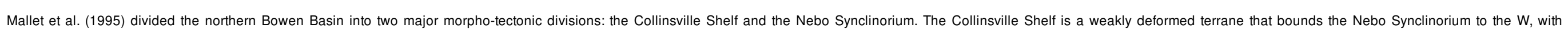

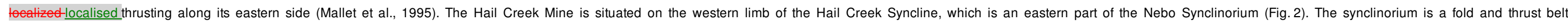

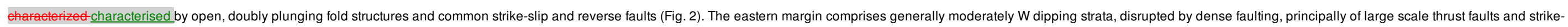

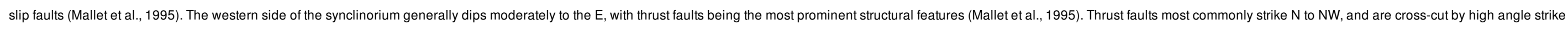
slip faults (Esterle et al., 2002).



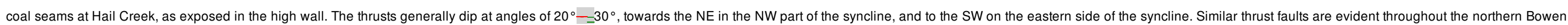




\section{ELSEVIER_TECTO_126344}

Basin (Korsch et al., 1992, 2009; Michaelsen and Henderson, 2000).


of intrusion and the thrust faulting described above. Malone et al. (1991) concluded that since the youngest local basaltic intrusions are Tertiary in age (Sutherland, 1978), the normal faults have a maximum Tertiary age.

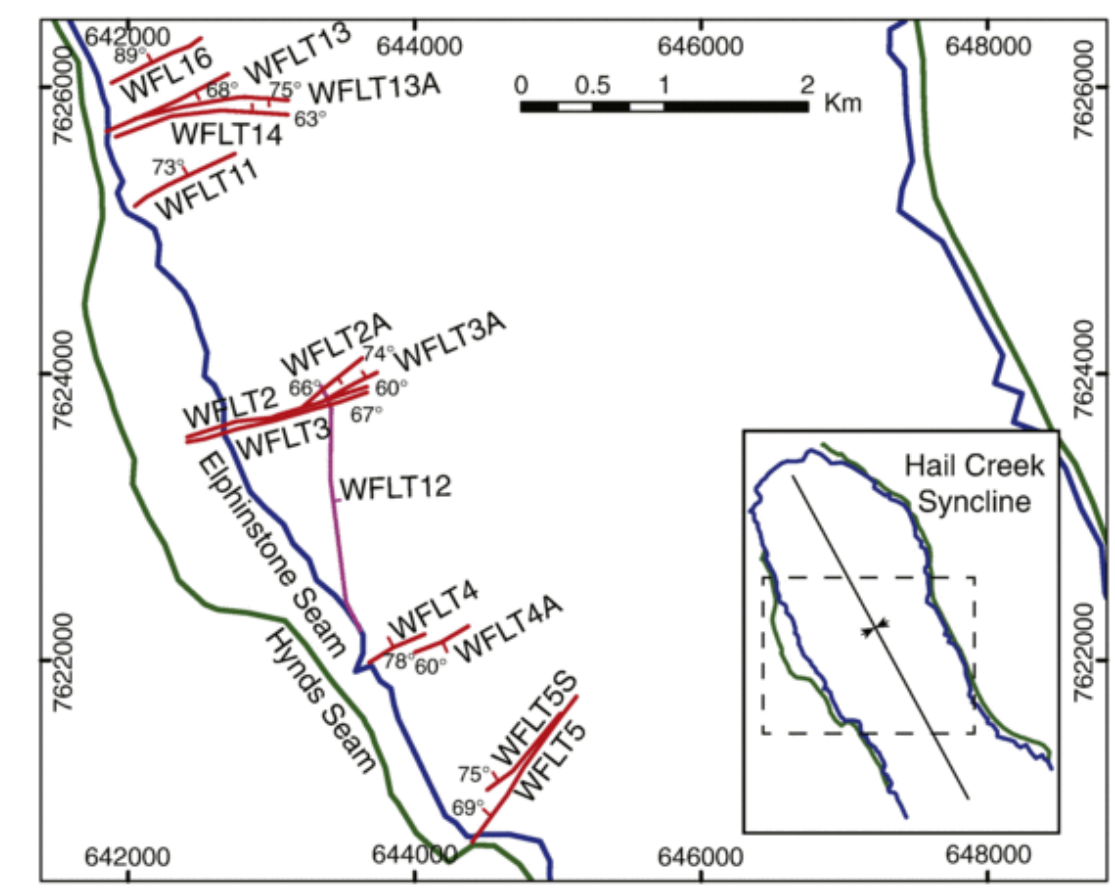

Fig. 3 Map of the faults examined at Hail Creek Coal Mine. The normal faults are grouped into four clusters of two to four faults, with average fault dips varying from $60^{\circ}-$ to $89^{\circ}$. Faults dip in four directions: SE, NW, NNW, and SSE, constituting a polymodal set.

\section{Data and methods}

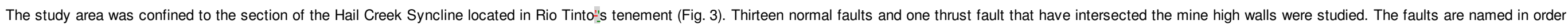

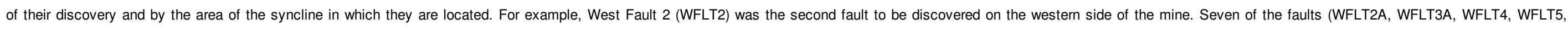

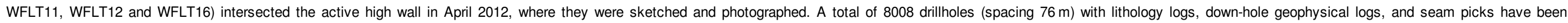

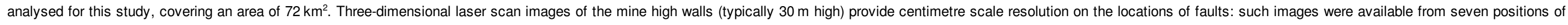
the high walls. An extensive photographic record of the walls was also utilised.

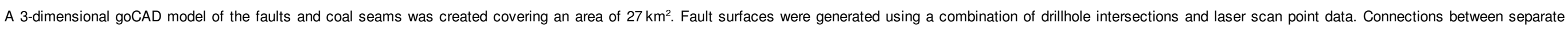

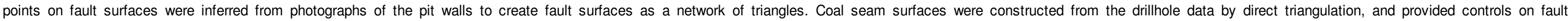

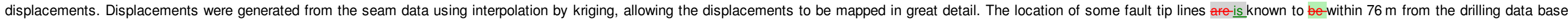



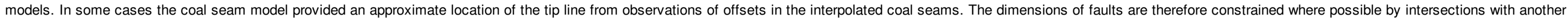
fault, drilling, or modelling.

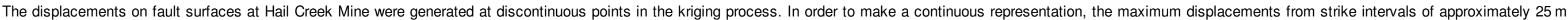

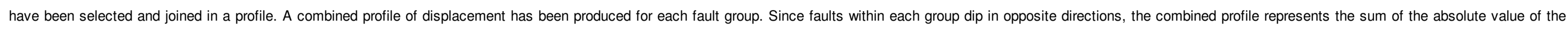




\section{ELSEVIER_TECTO_126344}

displacements, and does not show the net displacement from one side of the fault group to the other.

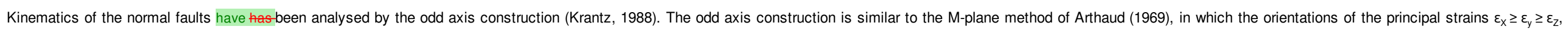

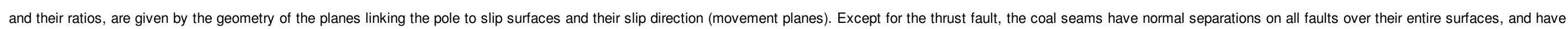

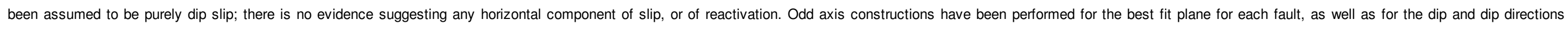
extracted from the triangles that make up the model of each fault, as explained in detail below.

\section{Individual fault descriptions}

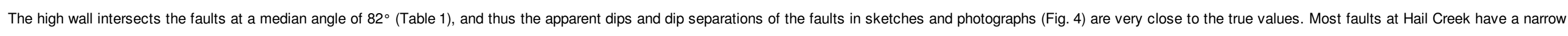

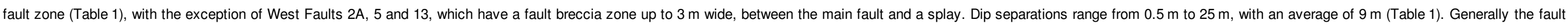


from the drilling data. The highest average dip occurs in the sandstone units followed by siltstone, etaystonetmudstone, coal and tuff respectively.

Table 1 Descriptions of faults and fault zones that were visible in the high wall at Hail Creek Coal Mine in April 2012. Dip Sep. is dip separation.

\begin{tabular}{|c|c|c|c|c|}
\hline Fault & Fault zone appearance & Dip Sep., m & Dip variation & Strike-section angle \\
\hline WFLT16 & Discrete & 0.5 & $\begin{array}{l}\text { Steep in sandstone } \\
\text { Shallow in siltstone }\end{array}$ & $85^{\circ}$ \\
\hline WFLT13 & Discrete except between the fault and splay up to $10 \mathrm{~m}$ from the intersection & 15 & No variation & $82^{\circ}$ \\
\hline WFLT2 & Zone of discrete faults $30 \mathrm{~m}$ wide & 3 & $\begin{array}{l}60^{\circ}=70^{\circ} \text { sandstone } \\
40^{\circ}=50^{\circ} \text { siltstone }\end{array}$ & $85^{\circ}$ \\
\hline WFLT2A & $\begin{array}{l}\text { Breccia zone } \\
2-3 \mathrm{~m} \text { wide }\end{array}$ & 10 & No variation visible due to fault breccia & $59^{\circ}$ \\
\hline WFLT3A & Discrete & 4 & $\begin{array}{l}65^{\circ} \text { sandstone } \\
40^{\circ} \text { siltstone }\end{array}$ & $69^{\circ}$ \\
\hline WFLT4 & Discrete & 7 & $\begin{array}{l}60^{\circ}=70^{\circ} \text { sandstone } \\
40^{\circ}=50^{\circ} \text { siltstone }\end{array}$ & $88^{\circ}$ \\
\hline WFLT5 & $\begin{array}{l}\text { Breccia zone } \\
2-3 \mathrm{~m} \text { wide }\end{array}$ & 25 & No variation visible due to fault breccia & $67^{\circ}$ \\
\hline
\end{tabular}




\section{ELSEVIER_TECTO_126344}





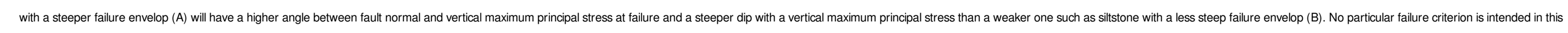
diagram. Sandstone and siltstone are used to illustrate the point because they are the most common rock types (Fig. 5).

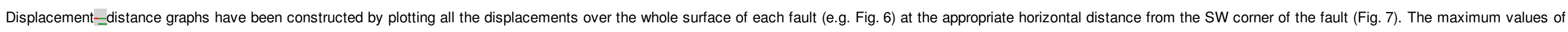

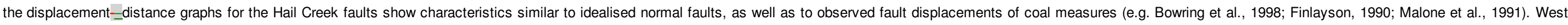

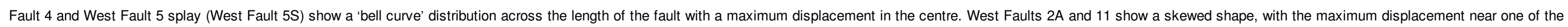
tips. The most common pattern is double displacement maxima (West Faults 16, 13A, 13, 12, 5, 4A, and 2). 


\section{ELSEVIER_TECTO_126344}

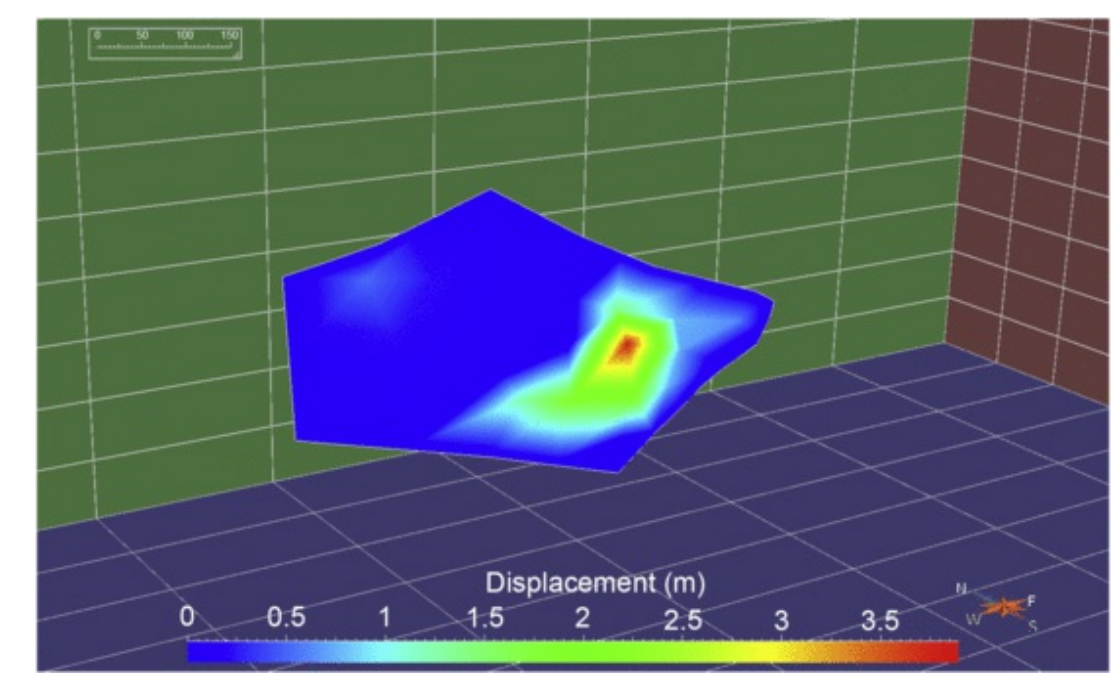

Fig. 6 Screen shot of typical fault surface model coloured by displacement, West Fault 13A. The single displacement maximum is over $4 \mathrm{~m}$. Approximate scale along axes is given in $\mathrm{m}$.




a)



c) West Fault 13A

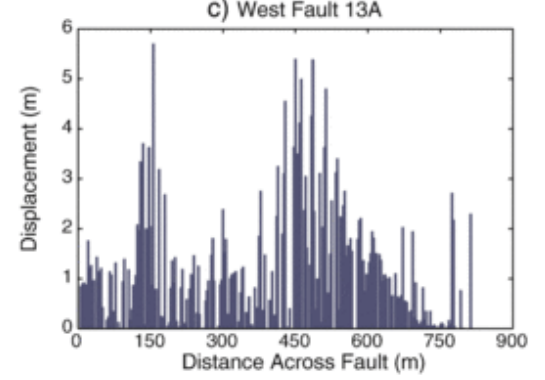

e) West Fault 11

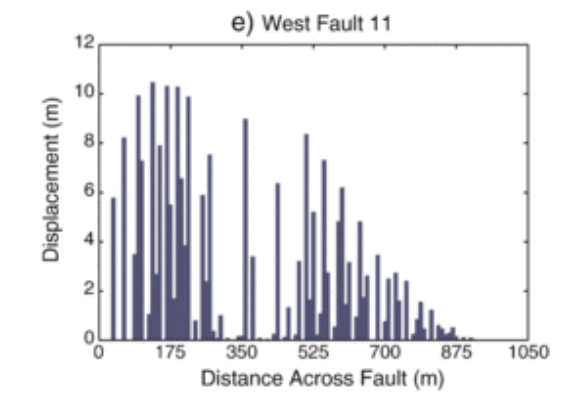

b) West Fault 13

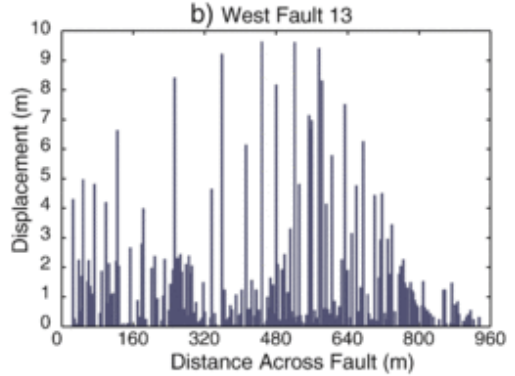

d) West Fault 14

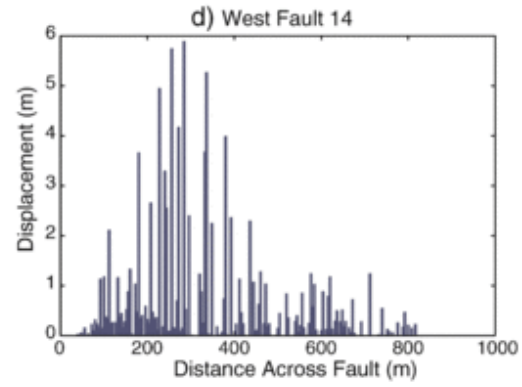

f) West Fault 2

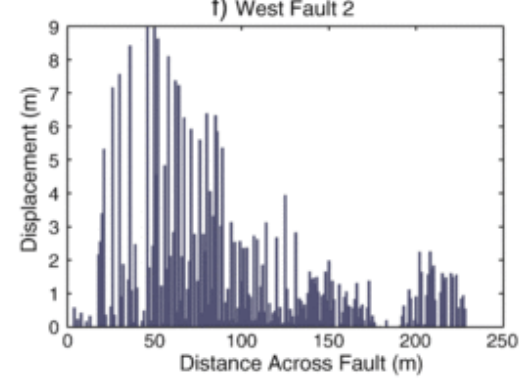


is unconstrained (Fig. 10). The partially constrained faults (West Faults 2A, 3, 3A 4A, 5S, 13, 13A and 14), plot well within an order of magnitude of the displacement versus length line of Kim and Sanderson (2005).

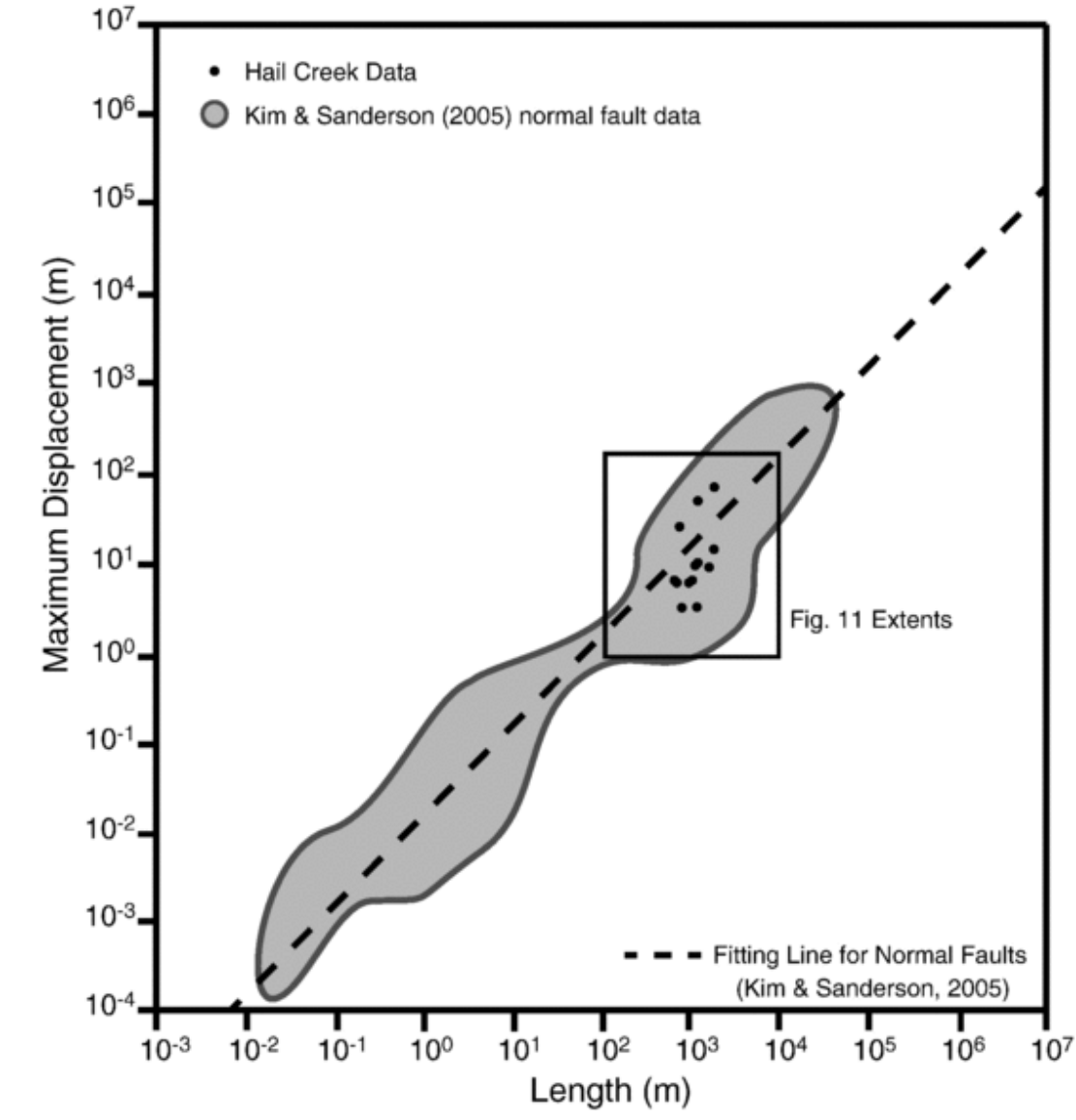

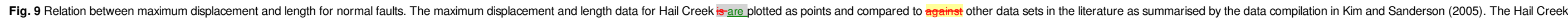
measurements fall within the range of existing data, and represent large displacement and length values relative to the whole data set.

Table 2 Fault dimensions from the fault model.

\begin{tabular}{|c|c|c|c|}
\hline Fault & Length, $\mathrm{m}$ & Maximum_displacement, m & Average displacement, $\mathrm{m}$ \\
\hline WFLT5 & 1488 & 73 & 17.7 \\
\hline WFLT5 Splay & 1002 & 52 & 16.1 \\
\hline WFLT4A & 581 & 6 & 3.2 \\
\hline WFLT4 & 622 & 26 & 8.5 \\
\hline WFLT12 & 2014 & 3 & 1.2 \\
\hline WFLT3 & 1406 & 15 & 4.1 \\
\hline WFLT3A & 561 & 7 & 3.7 \\
\hline
\end{tabular}




\section{ELSEVIER_TECTO_126344}

\begin{tabular}{|c|c|c|c|}
\hline WFLT2 & 1220 & 9 & 3.4 \\
\hline WFLT2A & 702 & 4 & 6.6 \\
\hline WFLT11 & 984 & 10 & 2.9 \\
\hline WFLT14 & 873 & 7 & 1.5 \\
\hline WFLT13A & 803 & 7 & 0.2 \\
\hline WFLT13 & 971 & 10 & 4.9 \\
\hline WFLT16 & 977 & 3 & 1.0 \\
\hline
\end{tabular}

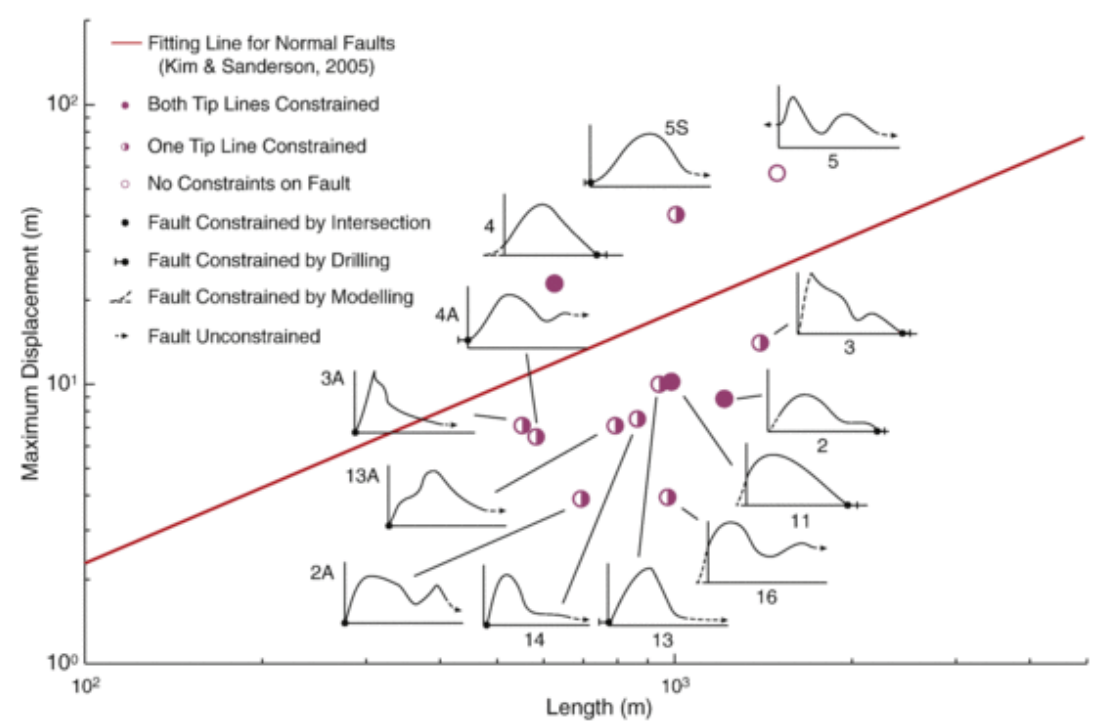

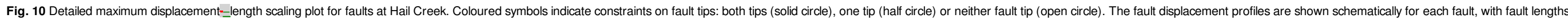
normalised to a single length. The fault lengths are constrained by intersection, driling, modelling or are unconstrained: these are shown as appropriate symbols on the schematic profiles.

\subsection{Fault system orientations and kinematics}

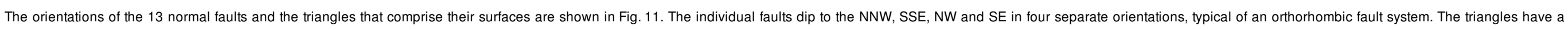
similar four-fold grouping, and show variable orientations within each group, with some triangles plotting in different fault sets. 


\section{ELSEVIER_TECTO_126344}

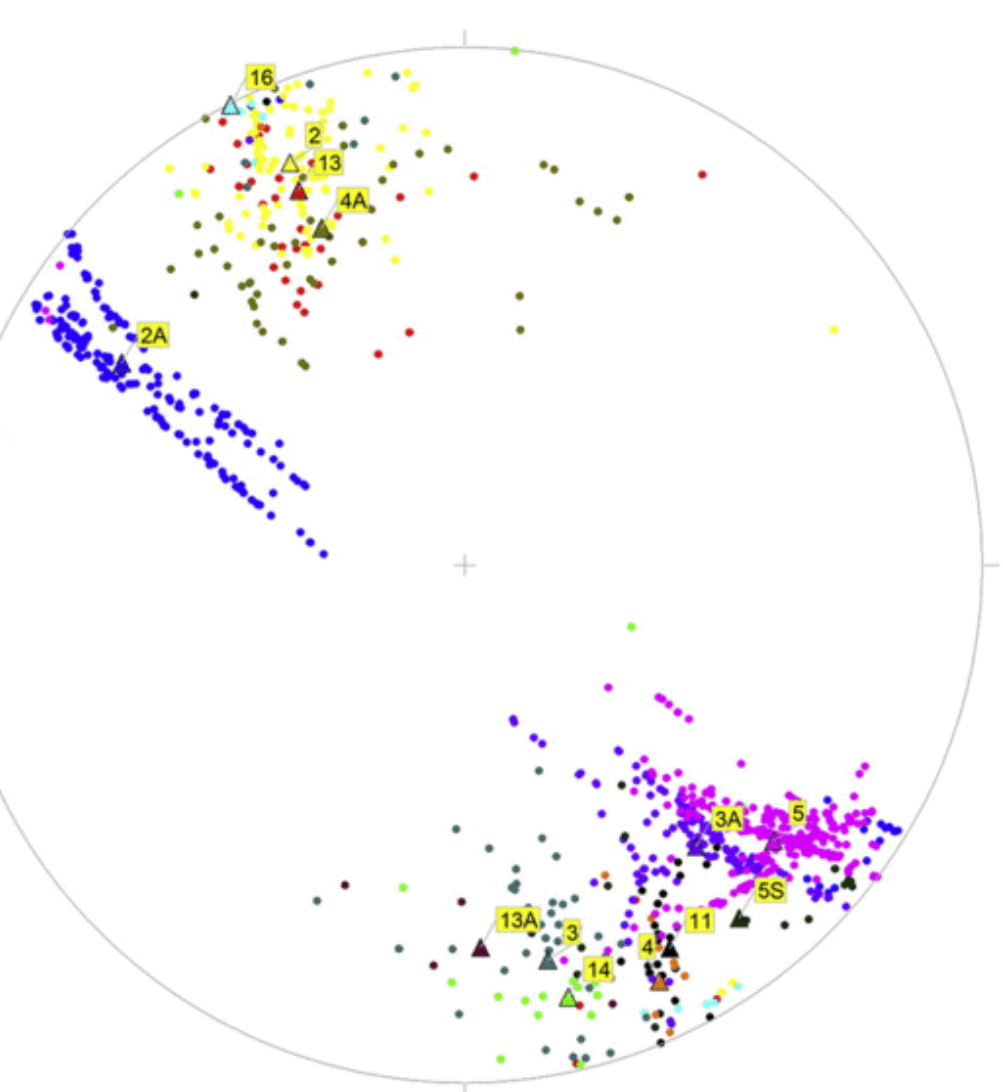

Fig. 11 Lower hemisphere, equal area stereoplot of poles to triangles on the 13 normal faults, with faults distinguished by colour. Triangles are the best fits.

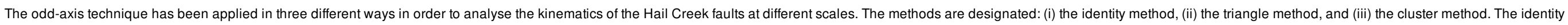

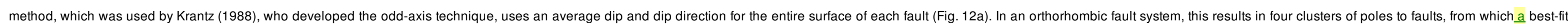

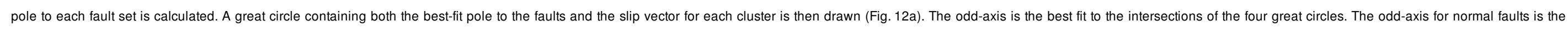


cf. Krantz, 1988) 

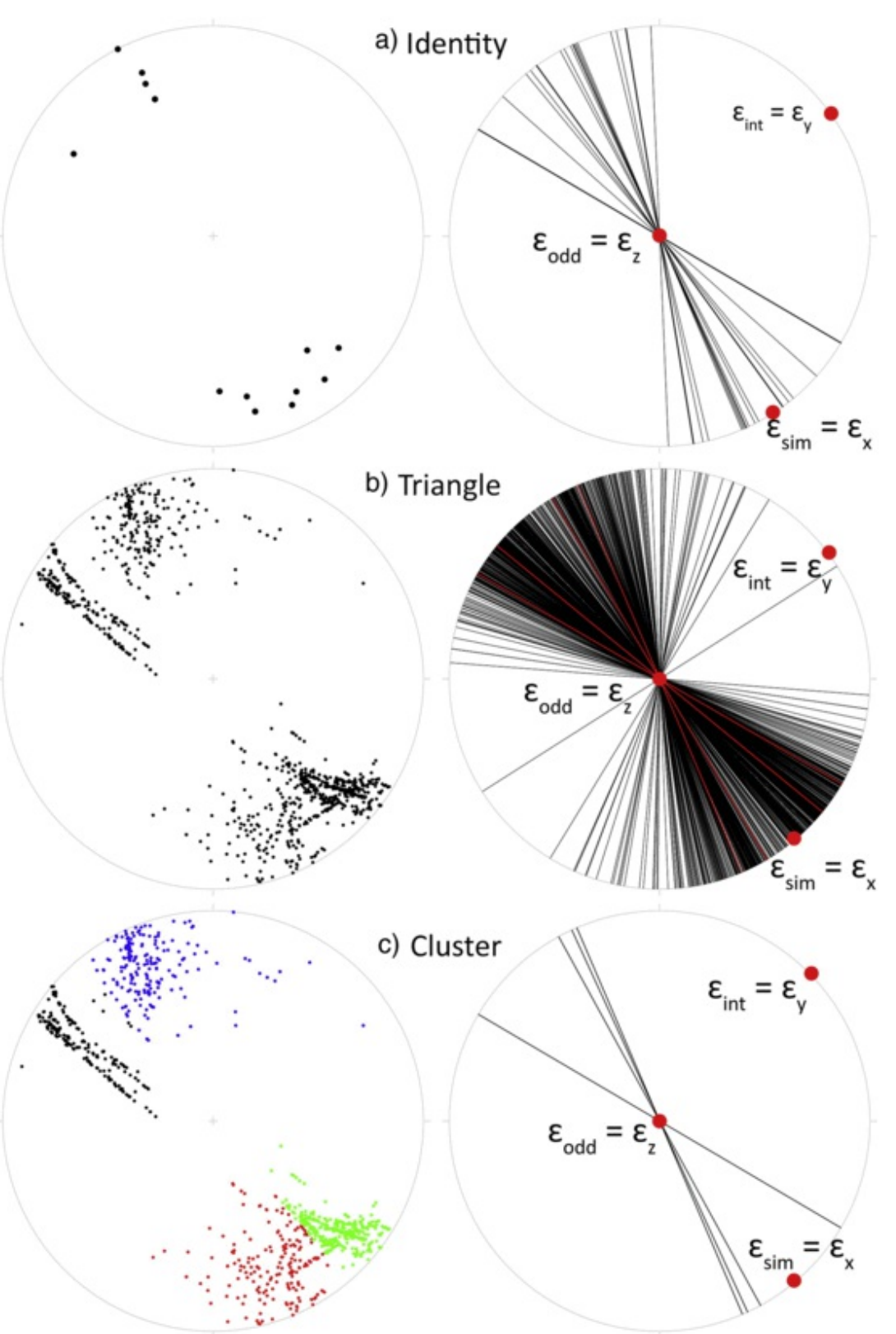

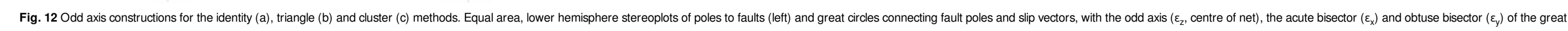
circles (right). All three methods give very similar orientations for the principal strains.



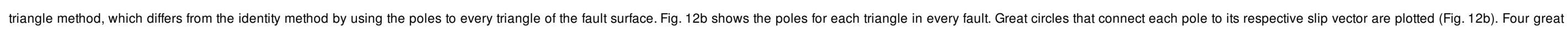




\section{ELSEVIER_TECTO_126344}

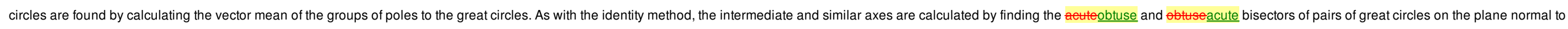
the odd axis.

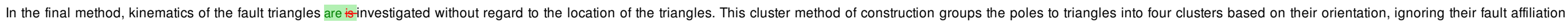

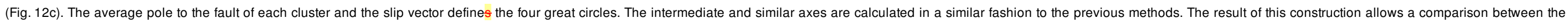
kinematics of individual fault components to the whole system, as shown by the identity and triangle methods.



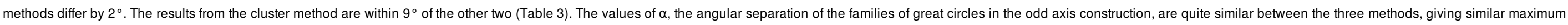
strain ratios $\varepsilon_{X} / \varepsilon_{Z}$ (ca.- $=0.9$ ). There is more variability in the other strain ratios (Table 3 ).

Table 3 Azimuths for the principal strains $\left(\varepsilon_{x}, \varepsilon_{y}+\downarrow\right), \alpha$ values, and principal strain ratios from the odd axis construction using the Identity, Triangle and Cluster methods.

\begin{tabular}{|c|c|c|c|}
\hline & Identity & Triangle & Cluster \\
\hline Azimuth of $\varepsilon_{\mathrm{x}}$ & 148 & 146 & 139 \\
\hline Azimuth of $\varepsilon_{\mathrm{y}}$ & 58 & 56 & 49 \\
\hline$\alpha$ & 20.75 & 26.75 & 18.15 \\
\hline$\varepsilon_{\mathrm{Y}} / \varepsilon_{\mathrm{x}}$ & 0.062 & 0.25 & 0.11 \\
\hline$\varepsilon_{\mathrm{\gamma}} / \varepsilon_{\mathrm{z}}$ & -0.058 & -0.20 & -0.097 \\
\hline$\varepsilon_{x} / \varepsilon_{z}$ & -0.94 & -0.80 & -0.90 \\
\hline
\end{tabular}

\section{Discussion}

\subsection{Displacement-Displacement-length scaling relationships of polymodal fault sets}

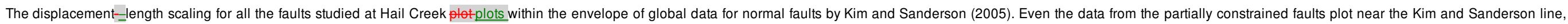

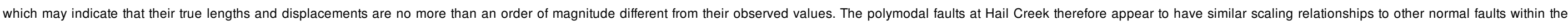

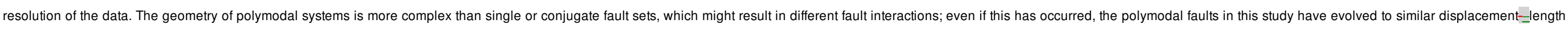
properties as other faults.

\subsection{Kinematic coherence of polymodal fault sets}

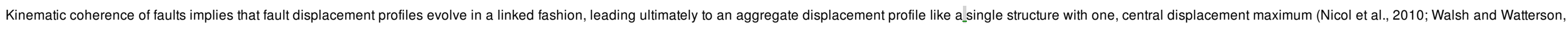



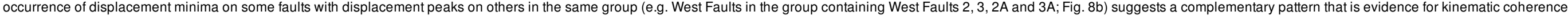

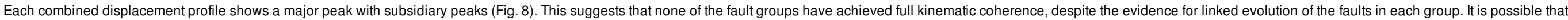


approximately parallel faults (e.g. Anders and Schlische, 1994; Dawers and Anders, 20041995; Nicol et al., 2005).

\subsection{Evolution of polymodal fault sets}






\section{ELSEVIER_TECTO_126344}

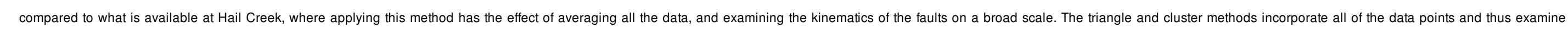


between SE and SSE.

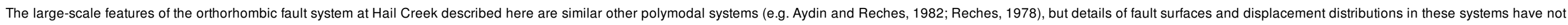
been described before. It is possible that the geometries, kinematics and evolution of the Hail Creek faults may be more generally applicable to polymodal systems.

\section{Conclusions}

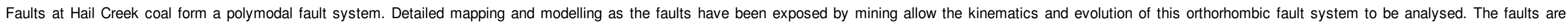

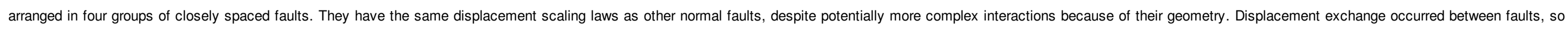



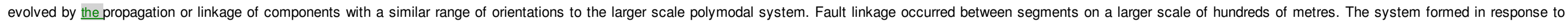
triaxial strain with a maximum extension orientated between SE and ESE throughout its history.

\section{Uncited reference}

Walshetal., 1991

\section{AcknowledgmentsAcknowledgements}

We are grateful to the staff of Hail Creek Mine for their assistance, and to the helpful journal reviews by Ze:ev Reches and Hengmao Tong.

\section{References}

Alves T.M., Scale-relationships and geometry of normal faults reactivated during gravitational gliding of Albian rafts (Espírito Santo Basin, SE Brazil), Earth Planet. Sci. Lett. 331-332, 2012, 80-96.

Anders M.H. and Schlische R.W., Overlapping faults, intrabasin highs, and the growth of normal faults, J. Geol. 102, 1994, 165-179.

Anderson E.M., The Dynamics of Faulting and Dyke Formation With Applications to Britain, 1951, Oliver and Boyd; Edinburgh.

Arthaud F., Méthode de détermination graphique des directions de raccourcissement, d'allongement et intermédiaire d'une population des failles, Bull. Soc. Géol. France 7 (11), $1969,729-737$.

Aydin A. and Reches Z., Number and orientation of fault sets in the field and in experiments, Geology 10 (2), 1982, 107-112.

Barnett J.A.M., Mortimer J., Rippon J.H., Walsh J.J. and Watterson J., Displacement geometry in the volume containing a single normal fault, Am. Assoc. Pet. Geol. Bull. 71, 1987, 925-937.

Bowring S.A., Erwin D.H., Jin Y.G., Martin M.W., Davidek K. and Wang W., U/Pb zircon geochronology and tempo of the end-Permian mass extinction, Science 280 (5366), 1998, 1039-1045.

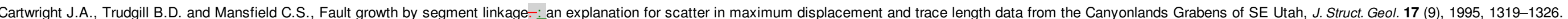
Cladouhos T.T. and Marrett R.A., Are fault growth and linkage models consistent with power-law distributions of fault length, J. Struct. Geol. 18, 1996, 281-294.

Clark R.M. and Cox S.J.D., A modern regression approach to determining fault displacement-_length scaling relationships, J. Struct. Geol. 18, 1996, 147-154.

Cowie P.A. and Scholz C.H., Growth of faults by accumulation of seismic slip, J. Geophys. Res. 97, 1992a, 11,085-11,095.

Cowie P.A. and Scholz C.H., Physical explanation for the displacement--length relationship of faults using a post-yield fracture mechanics model, J. Struct. Geol. 14 (10), $1992 b, 1133-1148$.

Dawers N.H. and Anders M.H., Displacement=-length scaling and fault linkage, J. Struct. Geol. 17 (5), 1995, 607-609.

Dawers N.H., Anders M.H. and Scholz C.H., Growth of normal faults--idisplacement-length scaling, Geology 21 (12), 1993, 1107-1110. 


\section{ELSEVIER_TECTO_126344}

Esterle J.S., Sliwa R., Smith L.G., Vincent J.R., Williams R., et al., Bowen Basin Supermodel 2000, 2002, CSIRO Exploration \& Mining; Kenmore, Qld.

Finlayson D.M.D.M., The Eromanga-=Brisbane Geoscience Transect: A Guide to Basin Development Across Phanerozoic Australia in Southern Queensland, In: Geology of Australia, 1990, Geoscience Australia.

Healy D., Jones R.R. and Holdsworth R.E., Three-dimensional brittle shear fracturing by tensile crack interaction, Nature (London) 439, $2006 a, 64-67$.

Healy D., Jones R. and Holdsworth R., New insights into the development of brittle shear fractures from a 3-D numerical model of microcrack interaction, Earth Planet. Sci. Lett. 249, $2006 \mathrm{~b}, 14-28$.

Jaeger J.C. and Cook N.G.W., Fundamentals of Rock Mechanics, 3rd ed., 1979, Chapman and Hall; London.

Kim Y. and Sanderson D.J., The relationship between displacement and length of faults: a review, Earth Sci. Rev. 68 (3-4), 2005, 317-334.

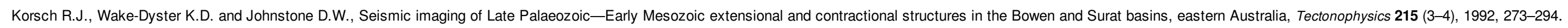

Korsch R.J., Totterdell J.M., Fomin T. and Nicoll M.G., Contractional structures and deformational events in the Bowen, Gunnedah and Surat Basins, eastern Australia, Aust. J. Earth Sci. 56 (3), 2009 , 477-499.

Krantz R.W., Multiple fault sets and three-dimensional strain;-:-theory and application, J. Struct. Geol. 10 (3), 1988, 225-237.

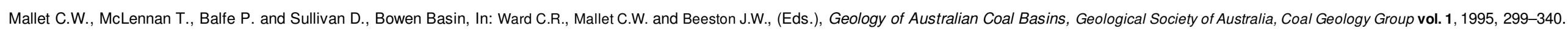

Malone, E.J., Corbett, D., Jensen, A.R., 1991. Geology of the Mount Coolon 1:250,000 sheet area. Dept. of National Development, Bureau of Mineral Resources, Geology and Geophysics.

Marrett R. and Allmendinger R.W., Estimates of strain due to brittle faulting: sampling of fault populations, J. Struct. Geol. 13, 1991, 735-738.

Michaelsen P. and Henderson R.A., Facies relationships and cyclicity of high-latitude, Late Permian coal measures, Bowen Basin, Australia, Int. J. Coal Geol. 44 (1), $2000,19-48$.

Muraoka H. and Kamata H., Displacement distribution along minor fault traces, J. Struct. Geol. 5 (5), 1983, 483-495.

Nicol A., Watterson J., Walsh J.J. and Childs S., The shapes, major axis orientations, and displacement patterns of fault surfaces, J. Struct. Geol. 18, 1996, 235-248.

Nicol A., Walsh J., Berrymana K. and Nodder S., Growth of a normal fault by the accumulation of slip over millions of years, J. Struct. Geol. 27, 2005, 327-342.

Nicol A. ., Walsh J.J.J.J., Villamor P., Seebeck H. and Berryman K.R.K.R., Normal fault interactions, paleoearthquakes and growth in an active rift, J. Struct. Geol. 32 (8), 2010 , 1101-1113.

Oertel G., The mechanism of faulting in clay experiments, Tectonophysics 2, 1965, 343-393.

Peacock D.C.P., Propagation, interaction and linkage in normal fault systems, Earth Sci. Rev. 58 (1-2), 2002, 121-142.

Peacock D.C.P. and Sanderson D.J., Displacements, segment linkage, and relay ramps in normal fault zones, J. Struct. Geol. 13, 1991, 721-733.

Reches Z., Analysis of faulting in three-dimensional strain field, Tectonophysics 47 (1-2), 1978, 109-129.

Reches Z., Faulting of rocks in three-dimensional strain fields $\frac{11-.}{2}$ Theoretical analysis, Tectonophysics 95 (1-2), 1983, 133-156.

Reches Z. and Dieterich J.H., Faulting of rocks in three-dimensional strain fields $\frac{\pi}{2},-$. Failure of rocks in polyaxial, servo-control experiments, Tectonophysics 95 (1-2), $1983,11-132$.

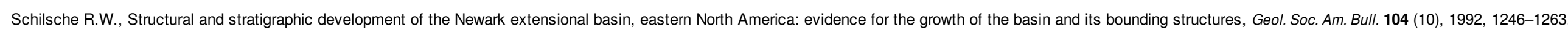

Sutherland F.L., Mesozoic-_Cainozoic volcanism of Australia, Tectonophysics 48 (3-4), 1978, 413-427, DOI: 10.1016/0040-1951(78)90126-9.

Walsh J.J. and Watterson J., Distributions of cumulative displacement and seismic slip on a single normal fault surface, J. Struct. Geol. 9 (8), $1987,1039-1046$.

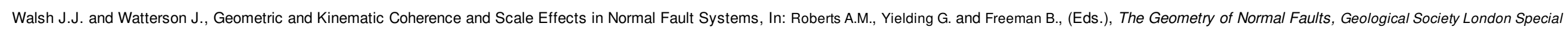
Publication 56, 1991, 193-203. 
Walsh J. and Watterson J., Geometric and kinematic coherence and scale effects in normal fault systems, Geol. Soc. Lond., Spec. Publ. 56, 2002, 193-203. Walsh d.-, Watterson d-and-Yielding G., The importanee of smalt-seale faulting in regional extension, Nature (London) 351 (6325), 1991, 391-393.

Walsh J.J., Nicol A. and Childs C., An alternative model for the growth of faults, J. Struct. Geol. 24 (11), 2002, 1669-1675.

Watterson J., Fault dimensions ;-_displacements and growth, Pure Appl. Geophys. 124 (1-2), 1986, 365-373.

Graphical abstract

\section{Polymodal fault sets evolved} from polymodal components

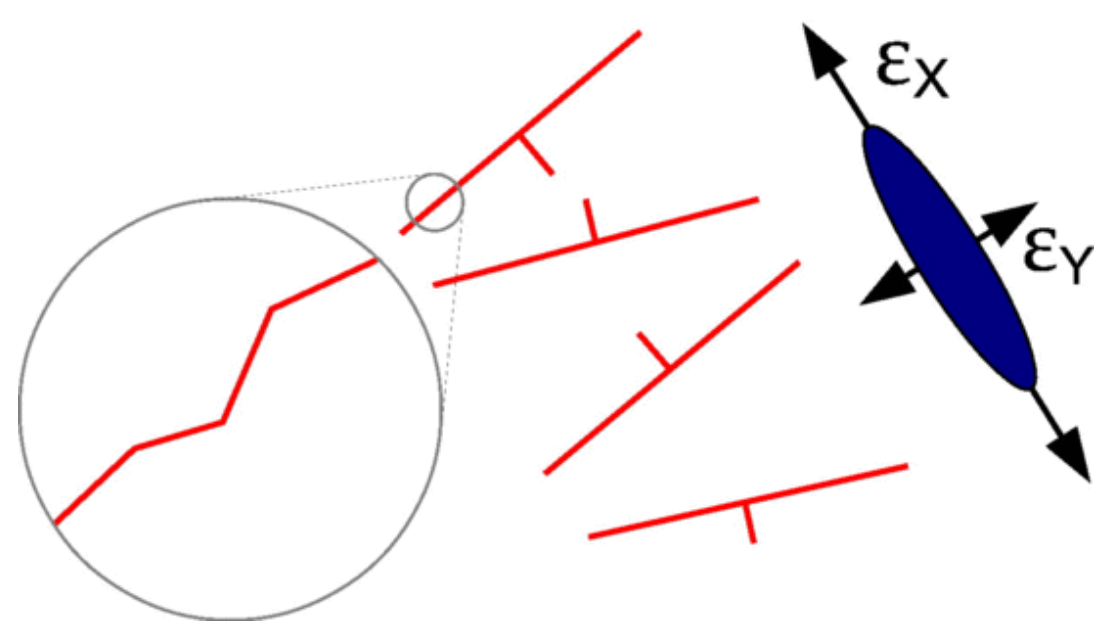

Highlights

- Coal seams are cut by normal faults in an orthorhombic network.

- The polymodal faults have typical displacement-_length ratios for normal faults_.

- Faults are kinematically coherent in groups.

- Faults evolved by growth of variably orientated components.

\section{Queries and Answers}

Query: 


\section{ELSEVIER_TECTO_126344}

\section{Answer: Yes, they are correct}

\section{Query:}

The citation "Cowie and Scholz, 1992" has been changed to match the author name/date in the reference list. Please check here and in subsequent occurrences, and correct if necessary.

\section{Answer: OK}

Query:

The citation "Walsh and Watterson, 1988" has been changed to match the author name/date in the reference list. Please check here and in subsequent occurrences, and correct if necessary.

Answer: OK

Query:

The citation "Michaelsen et al., 2000" has been changed to match the author name/date in the reference list. Please check here and in subsequent occurrences, and correct if necessary.

Answer: OK

Query:

The citation "Michaelsen et al., 2000" has been changed to match the author name/date in the reference list. Please check here and in subsequent occurrences, and correct if necessary.

Answer: OK

Query:

The citation "Michaelsen et al., 2000" has been changed to match the author name/date in the reference list. Please check here and in subsequent occurrences, and correct if necessary.

\section{Answer: OK}

Query:

This sentence has been slightly modified for clarity. Please check that the meaning is still correct, and amend if necessary.

\section{Answer: OK}

\section{Query:}

Citation "Dawers and Anders, 2004" has not been found in the reference list. Please supply full details for this reference.

Answer: Should be Dawers and Anders, 1995

Query:

This sentence has been slightly modified for clarity. Please check that the meaning is still correct, and amend if necessary.

Answer: OK

Query:

This sentence has been slightly modified for clarity. Please check that the meaning is still correct, and amend if necessary. 


\section{ELSEVIER_TECTO_126344}

Answer: Delete the "is". These events happened in the past

\section{Query:}

Uncited reference: This section comprises references that occur in the reference list but not in the body of the text. Please position each reference in the text or, alternatively, delete it. Thank you.

Answer: Delete this reference 